\title{
RESEARCH IN SP \\ PHYSICAL ACI \\ Immune and hematological characteristics of 2016 olympic champion shooting athlete: a case study investigation in transition period training
}

Autor(es): $\quad$ Bao, Vu Viet; Phuong, Le Quy

Publicado por: Imprensa da Universidade de Coimbra

URL persistente:

URI:http://hdl.handle.net/10316.2/44132

DOI:

DOI:https://doi.org/10.14195/2182-7087_ex2018_69

Accessed : $\quad$ 26-Apr-2023 14:44:02

A navegação consulta e descarregamento dos títulos inseridos nas Bibliotecas Digitais UC Digitalis, UC Pombalina e UC Impactum, pressupõem a aceitação plena e sem reservas dos Termos e Condições de Uso destas Bibliotecas Digitais, disponíveis em https://digitalis.uc.pt/pt-pt/termos.

Conforme exposto nos referidos Termos e Condições de Uso, o descarregamento de títulos de acesso restrito requer uma licença válida de autorização devendo o utilizador aceder ao(s) documento(s) a partir de um endereço de IP da instituição detentora da supramencionada licença.

Ao utilizador é apenas permitido o descarregamento para uso pessoal, pelo que o emprego do(s) título(s) descarregado(s) para outro fim, designadamente comercial, carece de autorização do respetivo autor ou editor da obra.

Na medida em que todas as obras da UC Digitalis se encontram protegidas pelo Código do Direito de Autor e Direitos Conexos e demais legislação aplicável, toda a cópia, parcial ou total, deste documento, nos casos em que é legalmente admitida, deverá conter ou fazer-se acompanhar por este aviso. 


\section{ANNALS OF RESEARCH IN SPORT AND PHYSICAL ACTIVITY}




\title{
IMMUNE AND HEMATOLOGICAL CHARACTERISTICS OF 2016 OLYMPIC CHAMPION SHOOTING ATHLETE: A CASE STUDY INVESTIGATION IN TRANSITION PERIOD TRAINING
}

\author{
Vu Viet Bao'; Le Quy Phuong1
}

KEYWORDS: Immune, hematologic, shooting, athlete, shooter, transition period training

The purpose of this study was to investigate the immune and hematological characteristics of the Vietnamese shooter who won gold medal in Olympic Rio 2016. The subject is a champion in $10 \mathrm{~m}$ air pistol (60 shots) men. He practiced 4 weeks after returning from Rio 2016 as transition period before starting new circle training. Blood was taken in the morning before meals at the end of transition period. Blood chemistry included white blood cell $(\mathrm{WBC})$, red blood cell (RBC), hemoglobin concentration (Hb), hematocrit (Hct), mean corpuscular volume (MCV), mean hemoglobin content $(\mathrm{MCH})$, mean corpuscular hemoglobin content (MCHC), platelets (PLT), and testosteron hormone, cortisol hormone, metanephrine/plasma were analyzied. The results show that almost indicator were in normal range: WBC $6.37 \times 10^{9} \mathrm{~L}$; PLT $208 \times 10^{9} \mathrm{~L}, \mathrm{Hb} 17.0 \mathrm{~g} / \mathrm{dL}$, Hct $47.8 \%$, MCV $83.9 \mathrm{fL}, \mathrm{MCH}$ 29.8 pg, MCHC $35.6 \mathrm{~g} / \mathrm{dL}$, except RBC $5.7 \times 10^{9} \mathrm{~L}$ was slightly higher than normal range (3.8$5.6 \times 10^{9} \mathrm{~L}$ ). Eventhough the athletes was 42 years old but his hormon and metabolic system were still in good condition. Compared to baseline values, testosteron $499.4 \mathrm{ng} / \mathrm{dL}$, cortisol $9.2 \mu \mathrm{g} / \mathrm{dL}$, adrenaline $65.0 \mathrm{pg} / \mathrm{ml}$, metanephrine/plasma $57.26 \mathrm{pg} / \mathrm{mL}$ were in normal range. This results demonstrated that elite shooter have a good response in immune and metabolic system. Training hard with the stress of focus and static strength has positive effects to shooting athlete and it still maintained a good response even during the transition period.

1 Hochiminh City University of Sport, Vietnam.

Email: vuvietbao@gmail.com 